\title{
Learning needs and life skills for youth: An introduction
}

\author{
Lene Buchert
}

Published online: 12 July 2014

(C) Springer Science+Business Media Dordrecht and UNESCO Institute for Lifelong Learning 2014

This introduction to the special issue of the International Review of Education (IRE) on "Learning needs and life skills for youth" has two main parts. The first part is a conceptual discussion of the learning areas identified for youth in the context of globalisation, marginalisation and rising unemployment levels worldwide. It is argued that the new kinds of skills and behaviour needed to sustain economic growth and development, and to permit individuals to lead autonomous lives - socalled "21st-century skills" - are often conflated with so-called "life skills", despite the latter term's stronger notion of whole-person development of individuals in view of their identity and self. In the second main part, this conceptual analysis then serves as the lens for a brief presentation of the papers in this special issue which discuss the topic from different perspectives in the contexts of Palestine and the broader Middle East and North Africa (MENA) region, China, Ghana, sub-Saharan Africa and Laos. The issue concludes with a brief consideration of the options for policy makers.

The current strong focus on youth must be understood in the context of the rapid worldwide changes we are experiencing due to globalisation, and the concern for the autonomy of the individual that is a central feature of modernity, democracy and the knowledge economy (Lauder et al. 2006). This implies understanding youth as a social rather than a biological construct. As in the case of other social groups, living conditions for youth vary depending, amongst other factors, on their gender, location, ethnicity and socio-economic background. A defining feature of the postmodern society, according to German sociologist Ulrich Beck (1992), is that individuals must design their own identities and life projects in processes of choice and reflexivity, and under circumstances where certainties no longer exist. These processes of choice and reflexivity are not to be understood as an extension of individuals' autonomous free decisions, but should rather be seen in the context of

\footnotetext{
L. Buchert $(\bowtie)$

Department of Education, University of Oslo, Oslo, Norway

e-mail: lene.buchert@iped.uio.no
} 
the functioning of social institutions which set boundaries to individual needs and opportunities. Education is one such institution which affects the life chances of individuals.

The common characteristic of youth worldwide is that they are in a transition stage between childhood and adulthood, meaning that they have to both take control of their personal lives and assume social commitments (UNESCO 2004a, p. 4) or, to put it another way, this is the time which "can offer most valuable opportunities to learn life skills and ground self-identity" (Perret-Clermont 2004, p. 4, as cited by Anna Bernhardt et al. in this special issue of the IRE). The current attention given to youth partly derives from the potential dangers which may follow from losing a generation of young people to unemployment at a time when the youth population (aged 15-24 years) is the highest ever in the world, standing at 1.8 billion (UN 2013 , p. 17) or one in six of the world's population (UNESCO 2012, p. 14). In the Arab region, one quarter of the youth population is unemployed, the highest rate in the world, followed closely by countries in Southern Europe witnessing equally high proportions as a result of the financial crisis in 2008 (IFC 2011; UNESCO 2012).

It has been estimated that 57 million jobs will need to be created by 2020 just to prevent unemployment rates from rising above current levels in the Arab States, South and West Asia, and sub-Saharan Africa (UNESCO 2014, p. 14). Sub-Saharan Africa faces a particular challenge since the region will account for, by far, the largest expected increase in the 0-14 age group by 2030 (UN 2011). It must, therefore, pay even more attention than other regions to the creation of educational and other opportunities for youth. Moreover, if, instead of age, the definition of youth takes into account the actual (adult) functions that many children, defined as being aged between 0 and 18 years (UNICEF 1989), actually perform in accordance with local cultural norms, the gravity of the situation would be even more apparent (see e.g. Kendall 2008).

One of the visible manifestations of the lack of jobs and other opportunities for youth is increased rural-urban, regional and international migration which often has disastrous personal consequences, as witnessed by the many tragedies in the Mediterranean. Another is the dissolution of social cohesion, as has been apparent during and after the Arab Spring in 2010. The two are strongly interlinked and can be explained partly by the hopes for a better future somewhere else raised through images of the "good life" in the media and the increased opportunities for travel (Beck and Beck-Gernsheim 2009). In reality, however, the concomitant development of globalisation and marginalisation has created pockets of inequality in all contexts, is restricting legal immigration into wealthy areas, notably Europe, and has created risks and uncertainties for young people at local, regional and global levels which unite them in decline (ibid.) rather than in opportunity.

The role of education in fostering economic growth and sustainable development has, therefore, been reinforced with particular attention to its link to the labour market, in part to create knowledge and a highly skilled workforce to ensure economic competitiveness in a global economy characterised by flexibilisation and deregulation. At the same time, its role in facilitating social cohesion and social justice remains pertinent, affecting the relationship among diversity, inclusion and citizenship. 
These emphases are apparent in the current attention being given to learning outcomes in curriculum and educational reform and in the discussions on Education for All (EFA) pre- and post-2015. One of the five shifts suggested by the United Nations' High-Level Panel for the post-2015 agenda is the transformation of economies "for jobs and inclusive growth" (UN 2013) in order to end extreme poverty and promote sustainable development. One of the goals set to accomplish this is the provision of quality education and lifelong learning. The targets include an increase in the proportion of adolescents who achieve recognised and measurable learning outcomes, an increase in the proportion of young and adult women and men with the skills needed for work, including technical and vocational ones, in addition to ensuring that every child completes primary education with minimum learning standards and that more children access and complete pre-primary education (ibid.).

The focus on quality education and lifelong learning has often rested on the idea that the learner needs to be at the centre of the teaching and learning process, and that the learner has different learning needs depending on a range of factors (location, gender, ethnicity, religion, special needs, etc.) which should be the starting point for successful learning outcomes (see e.g. UNESCO 2004b). In addition, and based on the principle of inclusion of all learners in the teaching and learning process, much attention has been given to how formal, non-formal and informal education could best be complementary and interlinked (see e.g. Hoppers 2002). This now includes the use of new learning modalities, such as the Internet, and the debate as to whether these could possibly replace traditional modalities for formal education, particularly at higher education levels (Lauder et al. 2006). There has also been focus on the need to ensure equivalency and formalisation of knowledge and skills acquired in non-formal and informal learning environments and of education degrees completed at different educational institutions in the world. Nevertheless, compartmentalisation and non-recognition of credentials still prevail in many contexts. This might also be an unintended consequence of associating foundational, transferable, and technical and vocational skills specifically with only primary and secondary education (UNESCO 2012), despite the rich offers of such skills at other levels and outside of formal education.

\section{Defining learning needs and life skills}

The kinds of knowledge and skills which should appear as learning outcomes have varied over time and place and are reflected in many different notions, sometimes for the same general areas. These have been defined in generic (general) rather than specific (diversified) terms, i.e. determined independent of individual learner backgrounds and needs. The most comprehensive - and fluid - term is perhaps "life skills" since, in terms of learning outcomes, it includes both learners' expected specific learning outcomes or cognitive skills (in e.g. literacy and numeracy) and expected behaviour and attitudes or non-cognitive skills (often also termed psychomotor skills or soft skills). In this understanding, education is mandated to do more than provide knowledge and skills for economic growth or poverty 
reduction as reflected in the notions of skills for work or skills for jobs, incomegeneration skills, entrepreneurship skills, and technical and vocational skills.

Life skills or skills for life are perhaps captured in the simplest and deepest way in the four pillars of learning of the Delors report (Delors et al. 1996), with outcomes of education relating to four crucial areas affecting a self-fulfilling life and contribution to societal development. They are (1) learning to know (i.e. to master the instruments of knowledge); (2) learning to do (i.e. to apply knowledge in practice); (3) learning to live together and living with others (i.e. to prevent and resolve conflicts, and promote peace and respect for other people, their cultures and spiritual values); and (4) learning to be (i.e. to ensure all-round development of each individual). Two additional pillars have since been suggested at the first World Forum on Lifelong Learning held in Paris in 2008: learning for change and transformation; and learning to become (Ouane 2008), precisely because of the rapid changes which are taking place in countries, regions and the world in general and in the life of individuals throughout their lifetime. Following on from the Faure report (Faure et al. 1972), life skills in this interpretation emphasise both wholeperson development (the "complete man") and a life-long learning perspective, i.e. learning throughout life.

In current discussions, life skills are often conflated with so-called " 21 st-century skills". This is particularly the case in contexts which emphasise individual competences to successfully meet varied, complex demands. In wealthier, high- and middle-level income countries, such as in member countries of the Organisation for Economic Cooperation and Development (OECD), and emerging economies, such as China (as discussed in this special issue of the IRE), 21st-century skills and competences include "psychosocial resources, including knowledge and skills, motivation, attitudes, and other social and behavioural components" (Schleicher 2007 , p. 349) to build the capacity or activate the innate ability of individuals to research and innovate and be flexible in order to sustain the construction of knowledge-based economies and societies. According to Andreas Schleicher (2012, p. 34), these skills can be grouped into four categories: (1) ways of thinking; (2) ways of working; (3) tools for working; and (4) skills for living in the world.

These four categories allude to, but are not identical with, the four learning pillars of the Delors commission. Both emphasise lifelong learning, but in contrast to the Delors report, the attention in Schleicher's four skills categories is on three generic instrumental competences rather than four intrinsic learning areas. They include the capacity to: (1) act autonomously and reflectively with respect to the physical and social environment, and at the personal level in terms of fulfilling personal goals; (2) use tools in the widest sense of the term, e.g. computers, language and knowledge, effectively in an interactive manner; and (3) form, join and function effectively and democratically in multiple, complex and socially heterogeneous groups - the latter being viewed as essential for a person's identity and self (Rychen and Salganik 2000).

In contrast, in the worst-hit regions in terms of unemployment and poverty, where countries continue to be dominated by large informal and farming sectors, as in most of sub-Saharan Africa, there continues to be much focus on formal, and now particularly secondary education, and on "catch up" or "minimal" skills. The latter 
are often provided in learning environments outside of the formal education system, particularly to those who did not attend or complete formal education or any other specialised training, i.e. youth and adults with low levels of education or none at all (see e.g. Hoppers 2002; UNESCO 2012, 2013/14; Fredriksen and Fossberg in this special issue of the $I R E$ ). However, there is also an increasing focus on life skills and 21st-century skills which are being re-conceptualised from a narrower economic purpose to their wider importance for human capital and human development as countries in sub-Saharan Africa undergo transitions towards more diversified economies (as discussed by Kwame Akyeampong in this special issue of the IRE).

\section{Analysing learning needs and life skills for youth}

The implication of these distinctions is, nevertheless, that the knowledge and skills which are to be provided to youth differ depending on context rather than needs, and that the instrumental, economic role of education takes precedence over its intrinsic, social and cultural role. This also becomes apparent in an analysis of the papers in this special issue of the IRE. In the first three papers, Ronald Sultana, Ewan Wright and Moosung Lee, and Kwame Akyeampong examine how education systems are used to provide life skills or 21st-century skills for youth in the MENA region, in particular in Palestine (Sultana), China (Wright and Lee), and sub-Saharan Africa, in particular Ghana (Akyempong). This is done especially from the perspective of the transition of youth from schooling to work, but with attention being given as well to their capacity to live full lives. In the following two papers by Birger Fredriksen and Camilla Helg $\phi$ Fossberg (sub-Saharan Africa), and Stephen Sparkes (Laos) and also in the note by Anna Bernhardt, Rika Yorozu and Carolyn MedelAñonuevo, the focus (partly) is on what governments, the private sector, international and technical assistance agencies, and non-governmental organisations can do to overcome barriers in education and society which prevent youth from selfdevelopment and assumption of their social commitment.

It has not been the specific purpose of any of the authors to discuss education as an institution which acts to include youth in or exclude them from societal opportunities. It is, nevertheless, possible to use this conceptual lens to understand, or at least make some speculative propositions about, the potential implications of applying life skills and 21 st-century skills in the ways and contexts discussed by the authors.

The presentation below in the second part of this introduction is, therefore, based on an understanding that education, like other institutions (e.g. state, market, community, kinship), operates according to rules and norms which determine, for economic and/or cultural reasons, whether individuals or social groups are either included in or excluded from education and society (Kabeer 2000). In this perception, exclusion is partly a consequence of state/government policies and actions (or inactions) - captured in the term "statal" (rather than "social") exclusion by the former United Nations Special Rapporteur on Human Rights, the late Katarina Tomaševski (2003, p. 198). According to social economist Naila 
Kabeer (2000), overcoming economic barriers to inclusion of excluded groups would necessitate redistribution of resources based on the principle of equality, whereas cultural barriers could be overcome through recognition of diversity and identity understood from an equity perspective.

The implication for education is that the state must retain the responsibility for its provision to youth in order to reconcile the needs of both individuals and society. This must be based on purposive efforts, including redistribution policies which are more than remedial, addressing underlying structural economic and cultural conditions and unequal access to power and resources. This includes facilitating access to education, i.e. to knowledge and understanding which are preconditions for individuals to act as informed citizens who can make considered life choices (Sen 1999). Access to forms of self-development, self-actualisation and empowerment is therefore essential to fulfil the social aspirations of the learner (Giddens 1991). This stands in contrast to learning skills which confine individuals more narrowly to being knowledge-worker citizens in a deregulated economic environment with a particular focus on their employment and employability from a market perspective (Lauder et al. 2006). This, then, also underlines the need for policy recognition of diversity and identity in order to overcome disadvantage understood as a result of societal processes, rather than as the fault or own making of what are considered to be "problematic" individuals or social groups.

\section{Conceptualisations of life skills and 21st-century skills in specific contexts}

The papers by Ronald Sultana, Ewan Wright and Mosung Lee, and Kwame Akyeampong demonstrate the continued fluidity of the terms "life skills" and " 21 st-century skills" and the importance of understanding them in particular local contexts despite the impact of globalisation. Although their common focus is the link between education and the labour market, the expected contribution of education - as interpreted in the terms life skills and 21 st-century skills - varies. This variation relates particularly to relative emphases on their importance for individual, personal development, and the development of the self, compared to their wider importance for economic development.

\section{MENA region and Palestine}

The attention given to human and individual aspects related to identity and culture seems to be comparatively stronger in the Arab context than in the cases of China and sub-Saharan Africa, when judged solely from the presented papers. Concerning the MENA region, and Palestine in particular, Ronald Sultana discusses the importance of providing youth with a set of life skills that entail competences enabling them to understand themselves and their environment, to make choices, and to plan and manage life transitions. This resonates with the first of the three competences identified above in the OECD context, but without the same instrumental emphasis. Youth acquire particular life skills, so-called DOTS (decision-making, opportunity awareness, transition and self-awareness), both 
informally outside of, and, increasingly, also within the formal education system through what is called "career guidance" or "livelihood planning". However, the kinds of choices that youth in the MENA region can make are not as "free" and market-determined as in the neoliberal tradition which underlies much of the thinking on globalisation.

Rather, as argued by Ronald Sultana, the choices of youth are limited by the surrounding collectivist culture and paternal authority structures as much as, if not more than, by the reality and restrictions of the labour market. Therefore, while DOTS are important for realisation of the self and personal identity, they do not necessarily lead to a "free" choice of education and occupation, neither for males nor for females. Traditional roles persist and are reflected in the available subject areas, work opportunities and working conditions for both men and women which then affect their personal life conditions. This also has an effect on social equity, since the labour market is dominated by micro-enterprises which are either familybased or otherwise require access through networks. Social capital therefore outweighs the importance of education per se.

Thus, the real barriers in the MENA region are structural and cultural. Education can, according to Ronald Sultana, help in strengthening awareness of actual opportunities and thereby reduce "frictional", as opposed to structural, unemployment. It could also contribute more to individual and societal development, provided that the difference in the value attached to humanistic, scientific and vocational education is addressed, since this influences students' current choice of study areas. The fact that the assessment and examination system is geared towards entry to higher education has the same effect.

\section{China}

In the case of China, as discussed by Ewan Wright and Moosung Lee, private International Baccalaureate Diploma Programme (IBDP) schools aim to help their students develop intellectual, personal, emotional and social skills to live, learn and work in a rapidly globalising world. The successful transition of youth into adulthood in the 21 st century therefore rests on educating the whole person and global citizens. This is done particularly in three "core requirements": Creativity, Action, Service (CAS); Extended Essay (EE); and Theory of Knowledge (TOK).

While there is some resemblance to Delors' four pillars of learning, there is more consistency with Schleicher's four 21st-century skills areas: ways of thinking; ways of working; tools for working; and skills for living in the world in view of the globalisation-induced transformations of societies. In this context, according to Ewan Wright and Moosung Lee, 21st-century skills are important to enhance economic competitiveness in the face of growing global economic integration and the shift of industrial structures towards service sectors, in favour of economic achievement on an individual scale. In addition, 21st-century skills are needed to prepare youth to live in multicultural, globally integrated societies due to widespread international migration and the impact of the Internet.

Twenty-first-century skills emphasise both inter-personal non-cognitive skills (adaptability, creativity, critical thinking and problem solving) and intra-personal 
non-cognitive skills (persistence, self-efficacy, time management and work ethic), alongside cognitive skills related to subject content and technical skills. The International Baccalaureate (IB) Learner Profile sets ten cognitive and noncognitive learning objectives which should result in graduates who are: "balanced, caring, communicators, inquirers, knowledgeable, open-minded, principled, reflective risk takers and thinkers" - characteristics which can be easily linked with postmodern thinking on individual autonomy and capacities needed to function in a rapidly changing knowledge economy and society in a globalised world.

However, despite the high esteem IBDP is accorded and the fact that China is the fastest-growing market for IBDP schools particularly in the metropolitan cities, these private schools are run in parallel to the government education system. According to Ewan Wright and Moosung Lee, access is predominantly restricted to non-Chinese students, i.e. children of expatriates who can afford to pay extravagant fees. While this may reflect government control of access to education for Chinese citizens, it removes a "choice" by the national elite for an alternative, internationally recognised programme. This may disadvantage them in the global labour market while simultaneously reinforcing existing inequalities in access to educational opportunities in China on a wider scale.

Furthermore, it is doubtful that IBDP programme schools can succeed in turning out global citizens and whole persons with the desired learner characteristics. This is because access to the kinds of high-ranking higher education institutions within and outside of China sought by IBDP graduates is determined by excellent performance and high grades in examinations based on content knowledge rather than personality features. Thus, as in Palestine, there are barriers to the successful implementation of the IBDP educational philosophy because of the examination system, the emphasis on standardised curricula, and teachers' incapacity to adopt pedagogical approaches to further and assess the desired non-cognitive skills.

\section{Sub-Saharan Africa and Ghana}

In the case of sub-Saharan Africa, and Ghana specifically, Kwame Akyeampong underlines the change in the notion of life skills as applied to secondary education. Secondary education is particularly important to young people because it is the path both to higher education and to the labour market. It represents a particular challenge in the African region, which is lagging behind other world regions in terms of enrolment levels. Life skills originally emphasised specific technical and vocational skills for employability or self-employment in particular occupations also termed "livelihood skills". Now, however, life skills take into account a flexible and portable set of skills which enable youth to adapt to changes in the world of work and lay the foundations for their productive well-being and behaviour.

These generic and adaptive life skills are also termed 21 st-century skills. They aim for more abstracted, undifferentiated knowledge-worker citizens who are more easily able to re-contextualise their skills in response to the uncertainty and change caused by globalisation and technological modernisation, much in accordance with those skills defined in the OECD context. According to Kwame Akyeampong, they 
include social and emotional skills, in particular communication, collaboration and creativity, and critical thinking skills. They all form part of the essential, and more specific, life skills which have been listed by the African Union as being important for secondary education, namely: "interpersonal skills, critical thinking, communication, entrepreneurship education, self-directed learning, civic/leadership skills education, and preventive health education covering HIV and AIDS, and malaria among others" (African Union 2006, p. 12).

This set of skills is considered to be essential for a country to achieve rapid economic growth, enabling it to react to the changes resulting from such economic growth and sustain economic development. In the context of Africa, these skills are considered important for growth of both the modern economy (agriculture, manufacturing and services) and of small-scale economic activities. They are also critical in their recognition of the diversified economies across Africa (see Fredriksen and Fossberg in this special issue of the IRE). According to Kwame Akyeampong, these skills were found to be missing in secondary school leavers in an employers' assessment of barriers to recruiting youth both in the increasingly dominant formal private sector and in the informal labour market in Ghana. This lack, according to the author, is due to the organisation of teaching and learning, and to the training of teachers.

Thus, despite the interpretation of 21 st-century skills as being relevant both for the world of work and employability, and for empowerment of individuals, their general well-being and quality of life, the economic relevance argument continues to prevail strongly. Birger Fredriksen and Camilla Helg $\varnothing$ Fossberg argue for a better alignment of the content of secondary education with labour market demands in sub-Saharan Africa. Kwame Akyeampong's discussion shows that 21st-century skills in Ghana relate more to local employment in the formal and informal sectors, than to whole-person development and global citizenship as in the case of IBDP schools in China, or to awareness of self and society as in Palestine. As in Palestine, the introduction of the full range of 21st-century skills in Ghana is hampered by the higher value assigned to content knowledge in curricula, and to assessment for progression to higher education. As in IBDP schools in China, the nature of the pedagogical practices in Ghana does not favour inquiry-based collaborative learning for which teachers have not been adequately trained in the first place.

Assuring life skills and 21st-century skills for youth: the role of providers of education

Thus, although the attention given to learning needs and life skills for youth seems to be quite strong, the starting point is not necessarily their own life situation in their particular context and what is needed to "ground self-identity" (Perret-Clermont 2004 , p. 4). Rather, generically identified skills for them to meet their "social commitment" take precedence, including a continued belief that the skills and values instilled through education can support social change. While such skills are broadly defined along cognitive and non-cognitive dimensions with a focus on interand intra-personal skills as well, the economic relevance argument seems to persist. 
Furthermore, the trust in education as a driver of individual and societal development is high despite the economic and cultural barriers preventing the education system from fulfilling its positive role. According to Naila Kabeer (2000), these barriers need to be addressed through redistribution of resources and recognition of diversity and identity in view of principles of equality and equity if education is to work against social exclusion.

As outlined above, there were some commonalities in the educational barriers identified by Ronald Sultana, Ewan Wright and Moosung Lee, and Kwame Akyeampong. These revolve around issues which have long plagued the development of education systems in general and have formed part of the design and implementation of policies related to education for the mind versus education for the hand. Thus, content knowledge continues to be more valued and assessed than practical and personality aspects despite the outlook of future societies. Teachers also continue to lack the pedagogical tools which would permit them to develop the kind of "whole" person who would embody 21 st-century skills or essential life skills to suit the needs of who and where they are. Some of the suggested solutions include teacher training, acknowledgement of the value of different kinds of education, and reviewing criteria for performance and progression in education.

Birger Fredriksen and Camilla Helg $\varnothing$ Fossberg identify yet other measures to address the learning needs of youth in sub-Saharan Africa, interpreted particularly from an economic relevance perspective. They consider relevant good-quality secondary education, including technical and vocational education supplemented by second-chance programmes for youth with low levels of education or none at all, as the bottleneck which needs to be overcome in order to ensure economic growth and development in sub-Saharan Africa. In their view, particular attention must be paid to building institutional capacity for leadership, accountability and innovation, and to addressing issues of cost and financing. The latter needs to include redistribution of resources within the education system in support of secondary education.

Birger Fredriksen and Camilla Helg $\varnothing$ Fossberg identify economic growth and increased taxation as the most sustainable sources for an increased government budget for education, while also stressing the important role of external aid agencies and private providers.

\section{Corporate social responsibility}

In specific cases, such as that of Statkraft discussed by Stephen Sparkes in the context of hydropower development in Laos, company involvement must adhere to the principles of corporate social responsibility in order to fulfil (Norwegian) government regulations. These are tied to United Nations principles on businesses and human rights aiming to protect citizens against human rights abuses - principles which sit well with strategies of redistribution of resources and recognition of diversity (and identity) - but with an effect which is largely limited to the local project area.

Stephen Sparkes demonstrates how profit and development go hand in hand in the hydropower development project by involving local stakeholders in open-ended consultations and dialogue on a range of preventive, proactive and compensatory 
measures. In addition to redistributive employment-related aspects, procurement of local materials for buildings and other infrastructure, livelihood restoration, sustainable use of natural resources and health interventions, education was addressed as an indicator of sustainable development. This involved both training for new or improved skills and tackling the (lack of) quality of the local education system through improving existing schools, and constructing and equipping new ones.

Particularly noticeable are educational non-formal activities addressing prevalent, gender-based social problems, in particular sexually transmitted diseases, human trafficking and prostitution, in a diversified way and in consideration of local values and conditions. This included paying attention to the cultural sensitivity of the issues (prostitution, for example, is illegal in Laos), and finding a way to engage males from the community and particular work places, such as bars, in the activities. This is also well-known from adult and non-formal education programmes implemented by non-governmental organisations in different regions of the world (see e.g. UNESCO 2012).

In Laos, local youth were engaged as educators and social change agents. They used locally produced culturally relevant educational materials in a range of activities for at-risk youth. According to Stephen Sparkes, the combined focus on atrisk youth and on youth as peer educators helped ensure a more lasting, long-term change of attitudes and behaviour by providing the knowledge and skills which are needed to address those very behaviours and attitudes in a new generation of youth, rather than only in the participating individuals.

\section{What policy makers can do}

In a similar vein, Anna Bernhardt, Rika Yorozu and Carolyn Medel-Añonuevo show the value of including youth in the planning, design and implementation of policies which aim to address their particular needs. The authors also provide examples of the kind of targeted, often second-chance non-formal education programmes discussed by Stephen Sparkes for Laos which are identified as important to overcome the bottleneck to growth and development in sub-Saharan Africa. As in Laos, these non-formal programmes have provided opportunities for taking into account diversity and identity and thereby addressed underlying cultural and economic societal barriers to participation from the perspective of individual needs.

While the wider effect of such programmes is questionable - in the case of Laos the number of youth involved was just under 4,000 people - they nevertheless show that education can be successfully used to address social exclusion at some level. However, as perhaps in the case of the suggested second-chance programmes for youth in sub-Saharan Africa, the risk is that youth continue to be exposed to compensatory programmes which provide only "minimal" skills which are neither recognised and formalised, nor ensure opportunities for truly improved life circumstances or full realisation of the self. This shows that these and other kinds of education activities cannot stand alone but need to be well integrated into wider education and other sector policies which are transformative rather than ameliorative in nature. 


\section{Conclusion}

Our current focus on youth is partly triggered by globalisation and its effects on societal and personal development. High unemployment levels and dissolution of social cohesion at national levels are accompanied by marginalisation of social groups and individuals within and across countries, with a particularly high impact on the youth population. As an institution, education has a critical role to play for the life chances of youth and their inclusion in or exclusion from social opportunities. The issue of learning outcomes is therefore central to policy discussions nationally and internationally.

Concomitant with the changes in the global market economy are defined kinds of knowledge and skills to be provided through education. The current notion of " 21 stcentury skills", which are deemed to ensure that individuals are flexible, adaptable and autonomous, often conflates with the notion of "life skills", irrespective of the latter term's originally stronger emphasis on whole-person development from a perspective which includes issues of identity and self as preconditions to perform autonomy. Therefore, despite the attention given to both cognitive and noncognitive skills in different regions and countries in the world, as exemplified in this special issue of the IRE, instrumental skills for economic development and the formation of knowledge-worker citizens have the upper hand. They prevail over the development of the intrinsic capacities for learning and acquisition of knowledge and understanding which individuals need to fulfil their multiple roles as informed citizens.

Governments must, therefore, retain their key responsibility for education and, as recommended in this special issue, implement reforms. These reforms need to address those learning barriers in education systems which are related particularly to the comparative value of different content areas of education, the capacity and possibility of teachers to address all learning areas, and the use of assessments and examinations as pedagogic tools to further the full set of learning areas. Just as important, if not even more so, is the need for governments to address wider issues of redistribution and diversity and identity to ensure that education functions as an inclusive rather than exclusive institution which, combined with other and wide-ranging efforts, can help overcome structural barriers to development.

Acknowledgements I sincerely thank Kwame Akyeampong, Wim Hoppers, Stephen Roche and Ronald Sultana for their valuable comments on an earlier version of this introduction.

\section{References}

African Union (2006). Second decade of education for Africa (2006-2015). Plan of action. African Union: Addis Ababa.

Beck, U. (1992). Risk society: Towards a new modernity. London: Sage.

Beck, U., \& Beck-Gernsheim, E. (2009). Global generations and the trap of methodological nationalism for a cosmopolitan turn in the sociology of youth and generation. European Sociological Review, 25(1), 25-36. 
Delors, J., et al. (1996). Education: The treasure within. Paris: UNESCO.

Faure, E., Herrera, F., Kaddoura, A.-R., Lopes, H., Petrovsky, A. V., Rahnema, M., et al. (1972). Learning to be. The world of education today and tomorrow. Paris: Fayard/UNESCO.

Giddens, A. (1991). Modernity and self-identity: Self and society in the late modern age. Cambridge: Polity.

Hoppers, W. (2002). Reconstructing youth development: A Southern African perspective. Africa Insight, $32(1), 8-15$.

IFC (International Finance Corporation) (2011). Education for employment: Realizing Arab youth potential. IFC: Washington D.C.

Kabeer, N. (2000). Social exclusion, poverty and discrimination. Towards an analytical framework. IDS Bulletin, 31(4), 83-97.

Kendall, N. (2008). Vulnerability in AIDS-affected states: Rethinking child rights, educational institutions and development paradigms. International Journal of Educational Development, 28(4), 365-383.

Lauder, H., Brown, P., Dillabough, J.-A., \& Halsey, A. H. (2006). Education, globalization and social change. Oxford: Oxford University Press.

Ouane, A. (2008). What stakes for the world forum on lifelong learning. 1st world forum on lifelong learning 28 and 29 October 2008. Paris: UNESCO. Accessed May 8, 2014, from http://www.wcfel. org/frenchbis/pdf/A\%20Ouane\%20texte\%20\%20Anglais.pdf.

Perret-Clermont, A.-N. (2004). Thinking spaces of the young. In A.-N. Perret-Clermont, C. Pontecorvo, L. B. Resnick, T. Zittoun, \& B. Burge (Eds.), Joining society: Social interaction and learning in adolescence and youth (pp. 3-10). Cambridge: Cambridge University Press.

Rychen, D. S. \& Salganik, L. H. (2000). Definition and selection of key competencies. In Fourth General Assembly of the OECD Education Indicators Programme. The INES Compendium. Contributions from the INES networks and working groups (pp. 61-73). Paris: OECD.

Schleicher, A. (2007). Can competencies assessed by PISA be considered the fundamental school knowledge 15-year-olds should possess? Journal of Educational Change, 8(4), 349-357.

Schleicher, A. (ed.). (2012). Preparing teachers and developing school leaders for the 21st century: Lessons from around the world. Background Report for the International Summit on the Teaching Profession. Paris: OECD. Accessed April 22, 2014, from http://www.oecd.org/site/eduistp2012/ 49850576.pdf.

Sen, A. (1999). Development as freedom. Oxford: Oxford University Press.

Tomaševski, K. (2003). Education denied. Costs and remedies. London: Zed Books.

UN (United Nations) (2011). World population prospects: The 2010 revision. Volume 1: Comprehensive tables. New York: UN.

UN (United Nations) (2013). A new global partnership: Eradicate poverty and transform economies through sustainable development. The report of the high-level panel of eminent persons on the post2015 agenda. New York: UN.

UNESCO (United Nations Educational, Scientific and Cultural Organization) (2004a). Empowering youth through national policies. Paris: UNESCO.

UNESCO (United Nations Educational, Scientific and Cultural Organization) (2004b). Education for All. The Quality Imperative. Education for All Global Monitoring Report 2005. Paris: UNESCO.

UNESCO (United Nations Educational, Scientific and Cultural Organization) (2012). Youth and Skills. Putting Education to Work. Education for All Global Monitoring Report 2012. Paris: UNESCO.

UNESCO (United Nations Educational, Scientific and Cultural Organization) (2014). Education for All Global Monitoring Report 2013/14. Teaching and learning for development. Paris: UNESCO.

UNICEF (United Nations Children's Fund) (1989). Convention on the rights of the child. New York: UNICEF.

\section{The author}

Lene Buchert (Denmark) has been Professor of Comparative and International Education since 2009 in the Department of Education, University of Oslo, where she leads the international two-year MPhil programme on Comparative and International Education. Since 2013 she has been working with Save the Children on a longitudinal "I'm Learning!" study in Cambodia, Uganda and Zimbabwe. From 1993 to 2009, Buchert held senior positions in different Departments of the education sector of UNESCO 
Headquarters in Paris. Prior to that, she worked as an international consultant and research fellow on education and development. Her most recent publication is a 2013 special issue of Prospects on Education, Fragility and Conflict, which she guest-edited and for which she wrote the introduction entitled Understanding Education, Fragility and Conflict [Prospects, XLIII(1), 5-15]. 